\title{
ANALISIS PROFIL MASYARAKAT DI PEMUKIMAN TEPIAN SUNGAI KAHAYAN KOTA PALANGKA RAYA KALIMANTAN TENGAH
}

\author{
Analysis of Community Profiles in Settlements on the banks of the Kahayan River, \\ Palangka Raya City, Central Kalimantan
}

Dileli Dharma Astoeti',

Sulmin Gumiri²,

Liswara Neneng ${ }^{3}$,

\section{Ardianoor $^{4}$}

'(Environmental Science

Student Doctoral Program of

Palangka Raya University,

Indonesia)

2(Environmental Science, Postgraduate of Palangka Raya

University, Indonesia)

3(Master of Management Science Study Program of Palangka Raya University, Indonesia)

${ }^{4}$ (Faculty of Agriculture of Palangka Raya University

*Kalimantan Tengah, Indonesia.

\begin{abstract}
Abstrak
Kalimanatan Tengah memiliki kekhasan geografis karena memiliki II (sebelas) sungai besar, anak-anak sungai dan ribuan cabang sungai kecil yang terhubung dengan danau oxbow (tapal kuda). Penelitian dilakukan di tiga titik lokasi, yaitu Kelurahan Tumbang Rungan dan Kelurahan Pahandut Seberang yang termasuk dalam Kecamatan Pahandut, serta Kelurahan Bereng Bengkel yang termasuk dalam Kecamatan Sabangau. Kelurahan Tumbang Rungan memiliki 2 RT dan I RW (BPS, 2020), berpenduduk 707 jiwa dengan 191 KK yang terdiri dari 357 orang laki-laki dan 350 orang perempuan (BKKBN, 2016). Kelurahan Pahandut Seberang memiliki I0 RT dan 2 RW (BPS, 2020), berpenduduk 1.663 jiwa dengan I.305 KK yang terdiri dari 830 orang laki-laki dan 833 orang perempuan (BKKBN, 2018), sedangkan Kelurahan Bereng Bengkel memiliki 6 RT dan I RW (BPS, 2020), berpenduduk 1.009 jiwa dengan $325 \mathrm{KK}$ yang terdiri dari $5 \mathrm{I} 3$ orang laki-laki dan 496 orang perempuan (BKKBN, 2017). Ketiga titik lokasi ini berada di pinggiran sungai yang berinduk pada Sungai Kahayan.Tujuan penelitian ini adalah mengnalisis profil masyarakat tepian sungai Kahayan Kota Palangka Raya. Pada penelitian ini menggunakan yaitu pengumpulan data dilakukan secara Kualitatif. Analisis data dilakukan menggunakan Kusiioner. Hasil: I) mayoritas bekerja sebagai buruh, 2) menggambarkan tingkat pendidikan responden, dimana mayoritas masyarakat memiliki tingkat pendidikan SLTP/sederajat 3) karakteristik seragam, dimana responden di Kelurahan Tumbang Rungan, Kelurahan Pahandut Seberang, dan Kelurahan Bereng Bengkel dominan berusia produktif,Kelompok usia responden dibagi menurut Depkes RI (2009), yaitu kelompok usia dewasa awal (usia 26-35 tahun), kelompok usia dewasa akhir (36-45 tahun) dan usia lansia ( $>46$ tahun). Berarti produktif menurut depkes sampai usia 45 tahun
\end{abstract}

\section{Kata Kunci:}

Usia Produktif,

Profesi Buruh,

Pendidikan SLTP,

Tepi Sungai Kahayan

Keywords:

Productive Age,

Labor Profession,

Junior High School Education,

Kahayan River Bank.

Accepted

Juli 2021

Published

Agustus 2021
Central Kalimantan is geographically unique because it has II (eleven) major rivers, According to data from the Palangka Raya City Health Office, in 2019, the research was conducted at three location points, namely Tumbang Rungan Village and Pahandut Seberang Village which are included in Pahandut District, and Bereng Bengkel Village which is included in Sabangau District. Tumbang Rungan Village has 2 RT and I RW (BPS, 2020), with a population of 707 people with 191 families consisting of 357 men and 350 women (BKKBN, 2016). Pahandut Seberang Village has 10 RT and 2 RW (BPS, 2020), has a population of I,663 people with I,305 families consisting of 830 men and 833 women (BKKBN, 2018), while Bereng Bengkel Village has 6 RT and I RW (BPS, 2020), has a population of I,009 people with 325 families consisting of 513 men and 496 women (BKKBN, 20I7). These three location points are on the banks of the river which is the mother of the Kahayan River.The purpose of this study was to analyze the profile of the Kahayan riverside community, Palangka Raya City. In this study, the data collection was carried out qualitatively. Data analysis was carried out using a questionnaire. Results: I) the majority work as laborers, 2) describe the education level of the respondents, where the majority of the people have a junior high school education level / equivalent 3) uniform characteristics, where respondents in Tumbang Rungan Village, Pahandut Seberang Village, and Bereng Bengkel Village are dominant in productive age, Group Respondents' age was divided according to the Indonesian Ministry of Health (2009), namely the early adult age group (age 26-35 years), the late adult age group ( $36-45$ years) and the elderly age ( $>46$ years). Means productive according to the Ministry of Health until the age of 45 years 


\section{Pendahuluan}

Bantaran sungai adalah ruang antara tepi palung sungai dan kaki tanggul sebelah dalam yang terletak di kiri dan/atau kanan palung sungai (Peraturan Menteri PU Nomor 28 tahun 2015). Area bantaran sungai merupakan area yang tepat berada di tepi sungai dan merupakan area yang tertutup oleh luapan air sungai saat banjir (floodplain). Bantaran sungai memiliki fungsi ekologis sebagai daerah penyangga daerah pengelolaan air dan merupakan jalur koridor hijau. Sebagai daerah penyangga dan jalur koridor hijau daerah bantaran sungai menjembatani keberadaan habitat dan ekosistem darat dengan perairan. Sehingga jika fungsi bantaran sungai terganggu, maka keberadaan habitat dan ekosistem juga akan terganggu. Terganggunya habitat dan ekosistem ini dalam jangka panjang dapat menyebabkan permasalahan lingkungan lain seperti pencemaran air, berkurangnya kemampuan tata kelola air dan iklim mikro (Waryono, 2009).

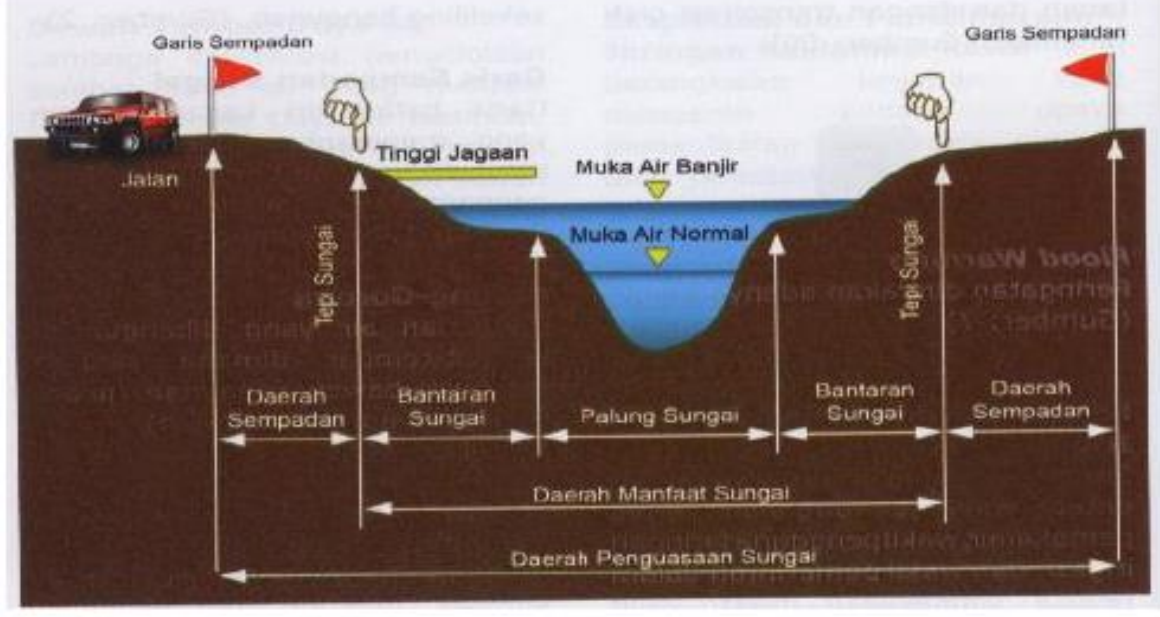

Gambar 2. I. Diagram Posisi Bantaran Sungai

(Sumber : http://pustaka.pu.go.id).

Berdasarkan Undang-undang No. I tahun 20II tentang Perumahan dan Permukiman terdapat pengertianpengertian sebagai berikut:

- Pengertian rumah adalah bangunan yang berfungsi sebagai tempat tinggal/hunian dan sarana pembinaan keluarga.

- Yang dimaksud dengan perumahan adalah kelompok rumah yang berfungsi sebagai lingkungan tempat tinggal/hunian yang dilengkapi dengan sarana dan prasarana lingkungan.

- Sedangkan permukiman adalah bagian dari lingkungan hidup di luar kawasan lindung (kota dan desa) yang berfungsi sebagai lingkungan tempat tinggal/hunian dan tempat kegiatan yang mendukung perikehidupan dan penghidupan.

Rumah merupakan bagian yang tidak dapat dilihat sebagai hasil fisik yang rampung semata, melainkan merupakan proses yang berkembang dan berkaitan dengan mobilitas sosial-ekonomi penghuninya dalam suatu kurun waktu.

Kalimantan Tengah adalah salah satu contoh kota di Indonesia yang memiliki banyak anak sungai dengan muaranya adalah sungai Kahayan. Tipologi mayoritas masyarakatnya bermukim dan menggantungkan hidup pada sungai. Sungai merupakan urat nadi perekonomian sebagai lahan mata pencaharian, sebagai tempat bermukim sekaligus sebagai prasarana transportasi masyarakat yang sangat besar pengaruhnya di dalam pola sosial dan budaya masyarakatnya, sehingga kota Palangkaraya dikenal dengan sebutan "Kota Air"(Hamidah, et all., 2013).

Sungai Kahayan memiliki lebar bantaran sungai $200 \mathrm{~m}$ dengan karakteristik setting keunikan aktivitas keseharian penduduk yang tinggal di tepi sungai kebanyakan merupakan komunitas tepian sungai secara fisik bentuk permukiman berkembang organik dan akrab dengan alam. Permukiman tepian sungai Kahayan di Kota Palangkaraya adalah permukiman awal memiliki keunikan pola permukiman memanjang mengikuti bentuk sungai. Orientasi rumah menghadap ke sungai sebagai bagian dari lingkungan permukimannya dan sebagai tempat yang menarik untuk bermukim. Menurut Tjilik Riwut (1979) dalam Elbas (1986) Struktur hunian kawasan tepian Sungai Kahayan ini berada di atas sungai dengan karakteristik keunikan rumah terdiri: I) rumah rakit (Raft House), 2) rumah tiang (Pillar House) dan 3) rumah beton (Permanent House).

Data jumlah penduduk yang bermukim di tepi sungai Tiap Kabupaten/Kota di Kalimantan Tengah, disajikan pada tabel 2.6. berikut ini:

Tabel 2.I. Data Jumlah Penduduk Yang Bermukim Di Tepi Sungai Tiap Kabupaten/Kota di Kalimantan Tengah

\section{No. Kabupaten/Kota Jumlah Penduduk (jiwa) Jumlah Penduduk yang bermukim ditepi} sungai (jiwa)

$\begin{array}{lll}\text { I } & \text { Kotawaringin Barat } & 269629 \\ 2 & \text { Kotawaringi Timur } & 41615 \\ 3 & \text { Kuala Kapuas } & 344955 \\ 4 & \text { Barito Selatan } & 130609\end{array}$


Dileli Dharma Astoeti, Sulmin Gumiri, Liswara Neneng dan Ardianoor. Analisis Profil Masyarakat di Pemukiman Tepian Sungai Kahayan Kota Palangka Raya Kalimantan Tengah

\begin{tabular}{llrr}
\hline No. & Kabupaten/Kota & Jumlah Penduduk (jiwa) & $\begin{array}{c}\text { Jumlah Penduduk yang bermukim ditepi } \\
\text { sungai (jiwa) }\end{array}$ \\
\hline 5 & Barito Utara & 126494 & 44273 \\
6 & Sukamara & 53190 & 13298 \\
7 & Lamandau & 71798 & 28719 \\
8 & Seruyan & 167621 & 41905 \\
9 & Katingan & 157654 & 70944 \\
10 & Pulang Pisau & 124015 & 55807 \\
11 & Gunung Mas & 107467 & 37613 \\
12 & Barito Timur & 110446 & 16567 \\
13 & Murung Raya & 107724 & 26931 \\
14 & Kota Palangka Raya & 252105 & 37816 \\
\hline
\end{tabular}

Sumber : Kalimantan Tengah Dalam Angka, 2018

Tabel diatas menyatakan bahwa total jumlah penduduk di Provinsi Kalimantan Tengah yang bermukim di tepi sungai sebanyak 860426 jiwa, dan khusus untuk kota Palangkaraya sebanyak 37816 jiwa. Keadaan ini bisa dikatakan sungai memiliki peran strategis sebagai salah satu sumber daya alam yang mendukung kehidupan masyarakat. Adapun peranan sungai di dalam konteks perkotaan menjadi sangat penting, khususnya dalam upaya mempertahankan sumber daya air yang berkelanjutan. Pengelolaan Daerah Aliran Sungai (DAS) merupakan salah satu aspek dari Pengelolaan Sumber Daya Air (PSDA) pada suatu Wilayah Pengembangan Sumber Air (WPSA) yang merupakan upaya pendayagunaan sumber air secara terpadu dengan upaya pengendalian dan pelestariannya. Pengelolaan DAS tidak terlepas dari berbagai permasalahan, antara lain masalah penurunan sumberdaya alamiah, polusi dari berbagai sumber, serta konflik penggunaan lahan di sekitar DAS (Clark, 1996).

Penelitian dilakukan di tiga titik lokasi, yaitu Kelurahan Tumbang Rungan dan Kelurahan Pahandut Seberang yang termasuk dalam Kecamatan Pahandut, serta Kelurahan Bereng Bengkel yang termasuk dalam Kecamatan Sabangau. Kelurahan Tumbang Rungan memiliki 2 RT dan I RW (BPS, 2020), berpenduduk 707 jiwa dengan I9I KK yang terdiri dari 357 orang laki-laki dan 350 orang perempuan (BKKBN, 2016). Kelurahan Pahandut Seberang memiliki 10 RT dan 2 RW (BPS, 2020), berpenduduk I.663 jiwa dengan I.305 KK yang terdiri dari 830 orang laki-laki dan 833 orang perempuan (BKKBN, 20I8), sedangkan Kelurahan Bereng Bengkel memiliki 6 RT dan I RW (BPS, 2020), berpenduduk I.009 jiwa dengan $325 \mathrm{KK}$ yang terdiri dari $5 \mathrm{I} 3$ orang laki- laki dan 496 orang perempuan (BKKBN, 2017). Ketiga titik lokasi ini berada di pinggiran sungai yang berinduk pada Sungai Kahayan.

Berdasarkan uraian diatas, maka penulis tertarik untuk meneliti lebih dalam tentang Profil masyarakat yang tinggal di pemukiman tepian sungai kahayan Kota palangka Raya dimana melihat profil masyarakat yang tinggal di pemukiman tepian sungai kota Palangka Raya.

\section{Metode Penelitian}

\section{I. Waktu dan Lokasi Penelitian}

Penelitian dilaksanakan pada bulan September sampai Desember 2020. Titik pengambilan sampel air ditentukan dengan sample survey method, yaitu metode pengambilan sampel dengan membagi daerah penelitian menjadi segmen atau titik yang diharapkan dapat mewakili populasi penelitian. Penentuan lokasi pengambilan sampel air dilakukan melalui tiga tahap yaitu koreksi geometrik, digitasi, overlay serta analisis lokasi. Koreksi geometrik dilakukan dengan rektifikasi dengan menggunakan sistem koordinat geografis dengan referensi World Geodetic System 1984 (WGS I 984).

Data Profil dikumpulkan melalui wawancara, kuesioner, dan observasi. Lokasi penelitian yaitu stasiun I yang mewakili daerah aliran sungai Kahayan Hulu berada pada bagian sungai di kelurahan Tumbang Rungan Kecamatan Pahandut Palangka Raya, stasiun 2 berada pada bagian Tengah sungai Kahayan di Kelurahan Pahandut Seberang, Kecamatan Pahandut Palangka Raya dan stasiun 3 berada pada bagian hilir sungai Kahayan di Kelurahan Bereng Bengkel, Kecamatan Sabangau, Palangka Raya (Gambar I).

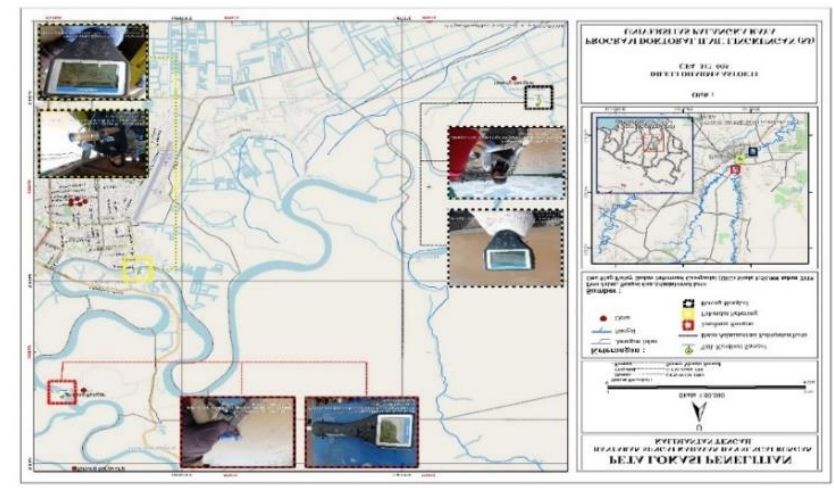

Gambar I. Lokasi pegambilan sampel 


\subsection{Populasi dan Sampel}

Data sosial diambil dari masyarakat yang tinggal di pemukiman di tepian Sungai Kahayan. Populasi penelitian adalah warga di 3 kelurahan, yaitu Kelurahan Tumbang Rungan, Kelurahan Pahandut Seberang dan Kelurahan Bereng Bengkel Kota Palangka Raya. Sampel penelitian ini diambil dari warga yang tinggal di tepian Sungai Kahayan Kota dengan menggunakan simple random sampling atau pengambilan sampel secara acak sederhana, dimana setiap anggota atau unit dari populasi mempunyai kesempatan yang sama untuk diseleksi sebagai sampel. Untuk mendapatkan jumlah sampel yang mewakili setiap desa maka diambil secara proporsional sesuai banyaknya KK di masing-masing Kelurahan. Besar sampel ditentukan menggunakan rumus:

$$
\begin{aligned}
& n=N / N^{2+1} \\
& \text { Keterangan } \\
& n=\text { Jumlah sampel } \\
& N=\text { Jumlah populasi } \\
& d=\text { derajat kepercayaan }
\end{aligned}
$$

Dengan jumlah KK sebanyak 2098 dan derajat kepercayaan sebesar $90 \%$ ditemukan sampel sebanyak 95 orang. Pemilihan responden dilakukan menurut kriteria yang telah ditentukan, yaitu kondisi perumahan, kelengkapan kondidi sanitasi, lingkungan di sekitar sesuai dengan parameter dan variabel yang digunakan.

\section{Analisis Data}

Penelitian dilakukan di tiga titik lokasi, yaitu Kelurahan Tumbang Rungan dan Kelurahan Pahandut Seberang yang termasuk dalam Kecamatan Pahandut, serta Kelurahan Bereng Bengkel yang termasuk dalam Kecamatan Sabangau. Kelurahan Tumbang Rungan memiliki 2 RT dan I RW (BPS, 2020), berpenduduk 707 jiwa dengan I9I KK yang terdiri dari 357 orang laki-laki dan 350 orang perempuan (BKKBN, 2016). Kelurahan Pahandut Seberang memiliki 10 RT dan 2 RW (BPS, 2020), berpenduduk I.663 jiwa dengan
I.305 KK yang terdiri dari 830 orang laki-laki dan 833 orang perempuan (BKKBN, 2018), sedangkan Kelurahan Bereng Bengkel memiliki 6 RT dan I RW (BPS, 2020), berpenduduk I.009 jiwa dengan $325 \mathrm{KK}$ yang terdiri dari $5 \mathrm{I} 3$ orang lakilaki dan 496 orang perempuan (BKKBN, 20I7). Ketiga titik lokasi ini berada di pinggiran sungai yang berinduk pada Sungai Kahayan.

Sungai Kahayan merupakan sungai terbesar yang membelah Kota Palangka Raya. Sungai Kahayan memiliki lebar rata-rata 450 meter dengan kedalaman rata-rata 7 meter. Panjang total sungai Kahayan $600 \mathrm{Km}$, dengan hanya $100 \mathrm{Km}$ diantaranya belum terlayari transportasi air (BPS, 2020). Hal ini mengindikasikan bahwa masyarakat banyak melakukan aktivitasnya di sepanjang sungai, terutama yang berdomisili di pinggiran sungai Kahayan.

\section{HASIL}

Pemukiman di pinggiran Sungai Kahayan terdiri dari dua kelompok, yaitu yang tinggal di rumah terapung (lanting) dan rumah panggung di daratan. Mayoritas penduduk menggantungkan hidupnya pada sungai, baik sebagai sumber mata pencaharian, jalur transportasi, maupun interaksi sosial dan budaya. Hal ini berpengaruh pada perkembangan pembangunan daerah pinggiran sungai. Akibat perkembangan tanpa perencanaan yang matang, pemukiman pinggiran sungai cenderung padat, tak teratur dan kumuh (Shinta, 2020).

Data terkait sanitasi dan hygiene diperoleh dari hasil jawaban responden terhadap pertanyaan - pertanyaan pada instrumen kuesioner. Responden merupakan masyarakat yang bertempat tinggal di tepian Sungai Tumbang Rungan, Sungai Kahayan Pahandut Seberang dan Sungai Bereng Bengkel. Jumlah total responden adalah 96 orang dengan latar belakang pendidikan, profesi, dan rentang usia yang berbeda.

Tabel 4. I.Gambaran Usia Responden

\begin{tabular}{cccc}
\hline Usia & Tumbang Rungan & Pahandut Seberang & Bereng Bengkel \\
\hline $30-35$ & 7 & 6 & 15 \\
$36-40$ & 11 & 8 & 12 \\
$41-45$ & 3 & 6 & 1 \\
$46-50$ & 5 & 4 & 2 \\
$>50$ & 6 & 8 & 2 \\
\hline
\end{tabular}

Sumber : (Dileli, 2020)

Kelompok usia responden dibagi menurut Depkes RI (2009) dalam Sonang (2019), yaitu kelompok usia dewasa awal (usia 26-35 tahun), kelompok usia dewasa akhir (36-45 tahun) dan usia lansia (>46 tahun). Berdasarkan tabel I, diketahui bahwa mayoritas responden dengan kelompok usia dewasa awal berada di Kelurahan Bereng Bengkel dengan nilai 15 responden. Responden dengan kelompok usia dewasa akhir mayoritas berada di Kelurahan Tumbang Rungan dan Kelurahan Pahandut Seberang dengan masingmasing 14 responden. Responden dengan usia lansia mayoritas berada di wilayah Pahandut Seberang dengan total 12 responden. Hal ini mengindikasikan bahwa mayoritas responden termasuk dalam usia produktif. 
Dileli Dharma Astoeti, Sulmin Gumiri, Liswara Neneng dan Ardianoor. Analisis Profil Masyarakat di Pemukiman Tepian Sungai Kahayan Kota Palangka Raya Kalimantan Tengah

Tabel 4. 2. Gambaran Pekerjaan Responden

\begin{tabular}{cccc}
\hline Pekerjaan & Tumbang Rungan & Pahandut Seberang & Bereng Bengkel \\
\hline Nelayan & 5 & 2 & 4 \\
Buruh & 13 & 15 & 16 \\
Pedagang & 6 & 6 & 5 \\
IRT & 6 & 7 & 6 \\
PNS & 2 & 2 & 1 \\
\hline
\end{tabular}

Sumber : (Dileli, 2020)

Kelompok pekerjaan responden terbagi atas kelompok nelayan, buruh, pedagang, IRT dan PNS. Dari keseluruhan responden di tiga lokasi, didapati bahwa mayoritas penduduk berprofesi sebagai buruh dengan jumlah 44 responden, sedangkan responden berprofesi PNS berjumlah paling sedikit dengan hanya 5 responden. Hal ini mengindikasikan bahwa mayoritas memiliki pekerjaan dengan aktivitas fisik yang cenderung lebih berat dibanding profesi lainnya.

Tabel 4. 3. Gambaran Pendidikan Responden

\begin{tabular}{cccc}
\hline Pendidikan & Tumbang Rungan & Pahandut Seberang & Bereng Bengkel \\
\hline Sarjana & 2 & 2 & 2 \\
SLTA Sederajat & 4 & 10 & 10 \\
SLTP Sederajat & 16 & 12 & 12 \\
SD Sederajat & 9 & 8 & 8 \\
Tidak Sekolah & 1 & 0 & 0 \\
\hline
\end{tabular}

Sumber : (Dileli, 2020)

Kelompok tingkat pendidikan responden terbagi atas kelompok berpendidikan sarjana, SLTA sederajat, SLTP sederajat, SD sederajat, dan yang tidak bersekolah. Dari keseluruhan responden, diketahui mayoritas penduduk berpendidikan SLTP sederajat dengan hanya 6 sarjana dan I responden yang tidak bersekolah. Hal ini mengindikasikan bahwa tingkat pendidikan di ketiga daerah ini cenderung rendah.

Berdasarkan pada pengisian dan pengembalian kuesioner 96 responden, maka karakteristik responden dapat diolah menjadi data demografi responden berupa usia, pekerjaan dan pendidikan. Selanjutnya profil masyarakat yang diteliti disajikan pada Gambar 4.I.

A. Usia

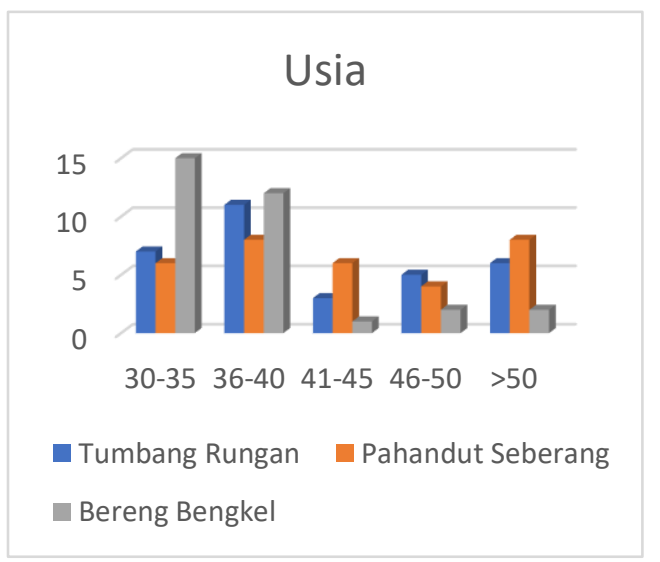

B. Pekerjaan

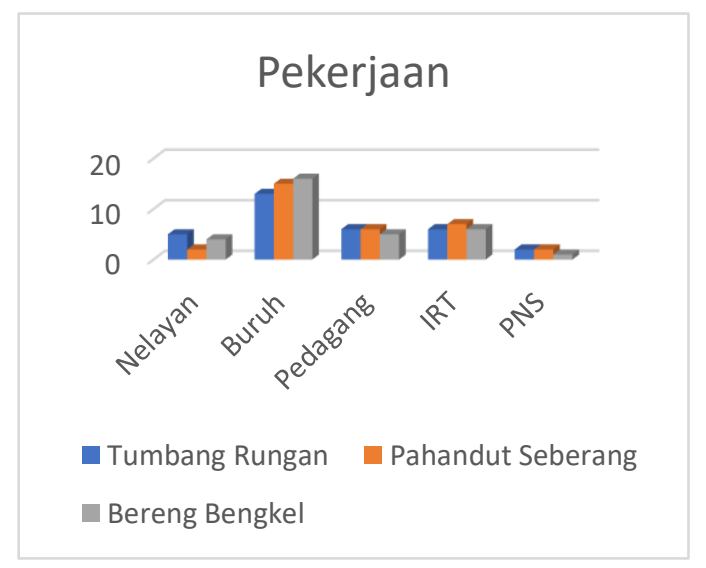




\section{Pendidikan}

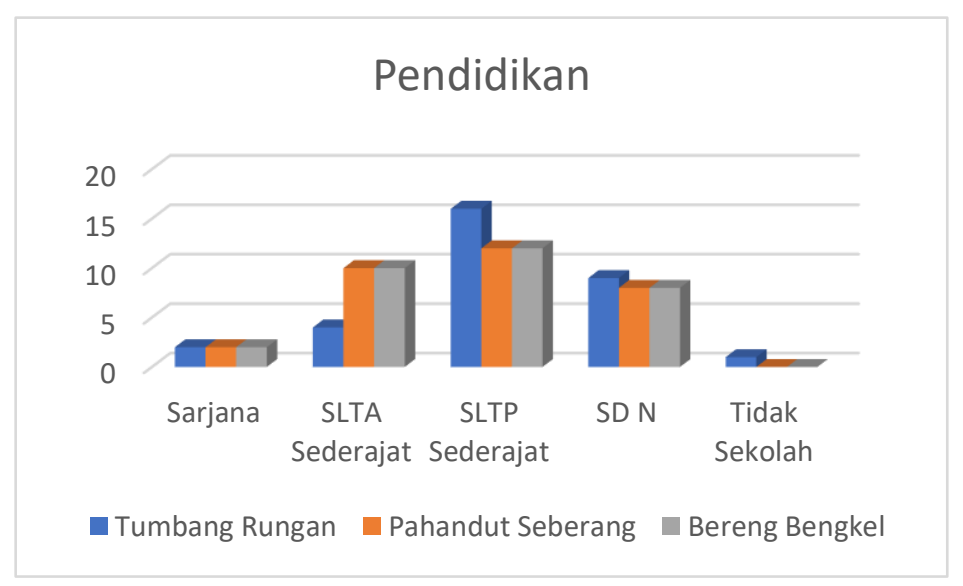

Gambar 4. I. Rekapitulasi Jawaban Responden Terhadap Instrumen Usia, Pekerjaan, dan Pendidikan

\section{Pembahasan}

Profil masyarakat di lokasi studi tergambar melalui jawaban responden terhadap pertanyaan mengenai usia, pekerjaan dan latar belakang pendidikan. Diketahui dari gambaran usia responden mayoritas responden termasuk dalam kategori usia dewasa, dimana pengelompokkan dilakukan sesuai pedoman Depkes RI (2009), yaitu kelompok usia dewasa awal (usia 26-35 tahun), kelompok usia dewasa akhir (36-45 tahun) dan usia lansia (>46 tahun). Karena mayoritas belum memasuki usia lansia, maka dapat dikatakan bahwa mayoritas responden di lokasi studi termasuk dalam kategori usia produktif. Gambaran pekerjaan responden menggambarkan pekerjaan yang dimiliki oleh responden, dimana mayoritas bekerja sebagai buruh. Faktor tingkat pendidikan kemungkinan besar berpengaruh terhadap jenis profesi yang dapat diperoleh, dimana ada pekerjaan yang memiliki spesifikasi tingkat pendidikan tertentu. Gambaran pendidikan responden menggambarkan tingkat pendidikan responden, dimana mayoritas masyarakat memiliki tingkat pendidikan SLTP/sederajat. Dari gambaran profil yang diperoleh, masyarakat di lokasi studi memiliki karakteristik seragam, dimana responden di Kelurahan Tumbang Rungan, Kelurahan Pahandut Seberang, dan Kelurahan Bereng Bengkel dominan berusia produktif, berprofesi sebagai buruh, dan berpendidikan SLTP/sederajat.

\section{Penutup}

\section{Kesimpulan}

Masyarakat di lokasi studi memiliki karakteristik seragam, dimana responden di Kelurahan Tumbang Rungan, Kelurahan Pahandut Seberang, dan Kelurahan Bereng Bengkel dominan berusia produktif, berprofesi sebagai buruh, dan berpendidikan SLTP/sederajat.

\section{Saran}

Perlu adanya sosialisasi pemberdayaan masyarakat yang spesifik untuk masyarakat tepi sungai untuk meningkatkan pengetahuan masyarakat terhadap sanitasi dan hygiene agar didapatkannya perubahan perilaku hidup bersih dan sehat

\section{DAFTAR PUSTAKA}

I. Asmawi, Suhaili, Muhammad Ahsin Rifa'i, Idiannor Mahyudin, dan Muhammad Ruslan, 2020. Protection of Turbidity on Reefs along the Southeast Coast of the Kalimantan during the 2015 El Niño

2. Bappeda Kota Palangka Raya, 2018. EHRA: Environmental Health Risk Assessment 2018.

3. Badan Kependudukan dan Keluarga Berencana Nasional, 2016. Profil Tumbang Rungan. https://kampungkb.bkkbn.go.id/kampungkb/profile//27 I. Diakses pada 24 Juli 202I. Pukul 10.10 WIB

4. Badan Kependudukan dan Keluarga Berencana Nasional, 2017. Profil Bereng Bengkel. https://kampungkb.bkkbn.go.id/profile/1949. Diakses pada 24 Juli 202I. Pukul I0.13 WIB

5. Badan Kependudukan dan Keluarga Berencana Nasional, 2018. Profil Pahandut Seberang. https://kampungkb.bkkbn.go.id/profile//6558. Diakses pada 24 Juli 202I. Pukul I0.15 WIB

6. Badan Pusat Statistik Kota Palangka Raya, 2020. Kota Palangka Raya dalam Angka. https://palangkakota.bps.go.id/publication/2020/04/27/ dcaedb06dab5bf3e9cladf0f/kota-palangka-raya-dalamangka-2020.html. Diakses Pada I5 Juli 202I. Pukul 10.10 WIB 